\title{
Challenges in the Governance of Community-Managed Forests in Ethiopia: Review
}

\author{
Mastewal Yami $^{1, *(1)}$ and Wolde Mekuria ${ }^{2}$ \\ 1 Independent Researcher, Addis Ababa P.O. Box 5689, Ethiopia \\ 2 International Water Management Institute (IWMI), East Africa and Nile Basin Office, \\ Addis Ababa P.O. Box 5689, Ethiopia; w.bori@cgiar.org \\ * Correspondence: mastewalyami@yahoo.com
}

Citation: Yami, M.; Mekuria, W. Challenges in the Governance of Community-Managed Forests in Ethiopia: Review. Sustainability 2022, 14, 1478. https://doi.org/10.3390/ su14031478

Academic Editor: Ivo Machar

Received: 28 December 2021

Accepted: 25 January 2022

Published: 27 January 2022

Publisher's Note: MDPI stays neutral with regard to jurisdictional claims in published maps and institutional affiliations.

Copyright: (C) 2022 by the authors. Licensee MDPI, Basel, Switzerland. This article is an open access article distributed under the terms and conditions of the Creative Commons Attribution (CC BY) license (https:// creativecommons.org/licenses/by/ $4.0 /)$.

\begin{abstract}
A large proportion of the rural population in Ethiopia depends on community-managed forests for food security and livelihoods. However, the government and development partners have paid little attention to the governance challenges which limit the contributions of communitymanaged forests to food security and livelihoods. Also lacking is a synthesis of evidence relating to the requirements for improved governance to support the efforts of decision makers and practitioners. This paper attempts to review and synthesize the available evidence with the aim of identifying the requirements to achieve improved governance in community-managed forests. The results revealed that failure to devise benefit-sharing mechanisms which consider the heterogeneity of rural communities was prevalent. Interference of local authorities and elite capture in decisionmaking processes of forest and landscape restoration also compromised the willingness of rural communities to engage in collective action. Requirements such as the identification of the needs of specific categories of communities and enabling of the negotiation of diverse interests in the design and implementation of interventions could improve the governance of community-managed forests. Developing management plans and business model scenarios which balance the ecological and socio-economic goals at a local level in collaboration with rural communities is important to improve the governance of community-managed forests. There is also a need to revisit the practice of evaluating the performance of community-managed forests almost exclusively based on the goals of climate change adaptation and mitigation and biodiversity conservation.
\end{abstract}

Keywords: deforestation; governance; incentives; livelihoods; restoration; sustainability

\section{Introduction}

Several approaches have been employed for realizing sustainable governance of community-managed forests across Africa, including decentralized forest management, collaborative forest management, community-based forest management and joint forest management $[1,2]$. Participatory approaches might differ with respect to the attention given to ownership, rights, and responsibilities, yet they have commonalities in their attention to the need for enabling local level forest governance. The approaches promote the devolution of more power to local communities and local authorities from higher level bureaucracies in the day-to-day governance of community forests. The shift has gained in popularity and has led to the design and implementation of interventions which take into consideration local needs and priorities.

Results have been mixed across countries due to differences in tenure security, community mobilization, aspirations, and the ownership of processes and outcomes of forest governance, market linkages, and incentives as mechanisms to encourage collective action. Further, the different approaches of managing community-based forest resources have been constrained by power imbalances among higher level and local level authorities and the lack of mechanisms for equitable benefit sharing from forests. Inadequate consideration of 
the economic concerns of local communities and gender issues have also constrained the success of managing community-based forests [3-6].

In recent years, there has been an increased understanding that governance of communitymanaged forests exhibits inadequacy in achieving positive livelihood outcomes. Policies and practices in several African countries paid little attention to governance aspects of community-managed forests $[7,8]$. At times, governance systems favored certain user groups with better access to resources, information, and diversified livelihoods over others [9]. The inadequacy of the governance system could have detrimental effect on the livelihoods of rural communities which depend on community-managed forests in Africa and elsewhere in the developing world [10,11]. Homogeneity, characterized as the extent of similarities in economic, socio-cultural, among other characteristics of user groups, has influenced the governance of community-managed forests [12,13]. Thus, internal, and external indicators are suggested for evaluating the governance of community-managed forests [14-16].

Attempts to address governance constraints in community-managed forests in the past decades has focused on strengthening local institutions and adjusting modes of interactions $[17,18]$. Institutions of both formal and informal natures also play important roles in community-managed forests. Formal institutions refer to the rules that guide access, control, and management, and which are backed up and enforced by the state [19]. Informal institutions are defined as systems of rules and decision-making procedures that have evolved from endogenous socio-cultural codes and give rise to social practices, assign roles to participants, and guide interactions among forest users [20]. Studies have pointed out the relevance of integrating the social networks and building trust among users of community-managed forests in the design and implementation of interventions [21,22]. Participation, equity, and accountability are the most relevant aspects of governance among users of community-managed forests [23].

In this paper, participation is defined as a process in which a range of stakeholders are involved in decision-making processes related to the governance of community-managed forests $[24,25]$. Level of participation could vary from high (citizen control) to low (manipulation) levels and it could have varied impacts on decision-making processes [26]. Accountability refers to the ability and willingness of different stakeholders in communitymanaged forests to take consistent actions and make decisions according to clearly defined and agreed-upon objectives [27]. Equity refers to fair benefit sharing and effective and meaningful participation of forest users in decision-making processes, as well as protection of the interests of vulnerable groups [28]. Performance is associated with the effectiveness of governance systems in improving forest conditions, socio-economic benefits, and addressing the inequity among gender and wealth groups [29]. Here, it is important to emphasize that key governance elements are interlinked, and in certain cases a clear distinction between them may not be possible.

In Ethiopia, the forests exhibit diversity in terms of climate and ecological contexts. The forests can be categorized as Afroalpine and sub-Afroalpine, dry evergreen montane and grassland complex, moist evergreen montane forest, Acacia-Commiphora woodland, Combretum-Terminalia woodland, lowland semi-evergreen forest, desert and semi-desert scrubland, and aquatic vegetation [30]. Estimates of the global forest resources assessment 2020 showed that forests account for $15.7 \%$ of the total land area in Ethiopia. Forests cover about 17 million hectares and other wooded lands cover 22.4 million hectares. Bamboo forest covers about 1.47 million hectares [31]. In Kenya, forests cover about 3.6 million hectares, and other wooded lands cover about 32.3 million hectares [32]. In Uganda, forests cover 2.3 million hectares and other wooded lands cover about 3.2 million hectares [33].

In Ethiopia, the history of community-managed forests has revealed dilemmas regarding who manages, uses, and owns the forests. Prior to 1975, community-managed forests had little or no recognition, as landlords administered most of the forests $[34,35]$. During the Derg regime (1975-1991), state ownership of forests presided, and community-managed forests were undermined [36]. The limited space given to local communities to negotiate 
their interests under centralized and authoritarian regimes and tenure insecurity also limited decision-making processes at short-term levels [37]. Rural communities depend on forest resources for income and livelihoods [38-40]. The mere emphasis on conservation outcomes in forest management undermines the needs for income and livelihoods among rural communities [41,42].

The realization of the limitations of forest governance systems led to the development of the Ethiopian Forestry Action Program (EFAP) in 1994 following a rigorous process and the involvement of technical experts across the nation [43]. Although, the federal and regional action plans lacked proper implementation, they enabled rural communities to manage forest resources in their vicinities $[44,45]$. This situation has opened opportunities for the expansion of different community-managed forests, such as community woodlots and exclosures $[46,47]$. While the ownership of the community-managed forests remains with the state, rural communities contributed labour either voluntarily or in exchange for wages under social protection schemes [48,49].

In Ethiopia, community-managed forests are governed under diverse institutional arrangements. The institutional context in turn influences the level of community participation, leadership responsibilities and commitments, and levels of public contributions to collective action. Again, government entities and technocrats might have different levels of engagement although the structures seem similar in their underpinnings. For instance, the case of exclosures in Tigray shows that local communities and governmental and nongovernmental organizations participate in identifying areas for establishing exclosures in a joint decision-making process [50]. The local communities participate in a general assembly to approve the identified priority areas, assign a leadership committee and guards, and develop village bylaws for defining forest use and user groups, mobilizing collective action for the maintenance and protection of the exclosures, and benefit-sharing mechanisms [51]. The guards and village leadership committee enforce the bylaws using monetary and non-monetary sanctions based on the agreement reached in the general assembly. The village bylaws might be submitted to a village judiciary, enabling enforcement on those who do not abide by the rules [52].

The experience in northwestern Ethiopia shows some similarities in the procedures of exclosure establishment and the institution of bylaws. However, several bodies, such as community watershed committees, local political leadership, and district agricultural offices participate, in the enforcement of bylaws. The establishment of Participatory Forest Management (PFM) cooperatives has been common in Oromia regional state. PFM cooperatives are established using the principle of 'voluntary' cooperatives, with the guidelines set by the cooperative agency at wereda levels. PFM cooperatives could manage areas identified as PFM sites and/or exclosures in a more or less similar manner. For instance, the user groups of exclosures and their agreed-upon bylaws would be registered by the cooperative agency as PFM cooperatives in West Arsi, Oromia. In some resource-rich areas, such as the Bale Eco-region, the PFM cooperatives and the Oromia Forest and Wildlife Enterprise (OFWE) share economic benefits from the community-managed forests [53]. Thus, the institutional arrangements governing community-managed forests across Ethiopia show diversity in terms of their levels of formality and levels of embeddedness in government institutions.

The community-managed forests employ different enforcement mechanisms. For instance, religious values guide the norms on what is right and wrong to do in the Ethiopian Orthodox Tewahido Church (EOTC) forests [54,55]. On the other hand, bylaws established by rural communities with or without the involvement of government bodies and non-governmental organizations (NGOs) support the management of woodlots and exclosures [52,56]. However, community-managed forests in Ethiopia exhibit governance constraints caused by internal factors that are context-specific, such as power relations and lack of trust among users [35,57], and an inability to achieve local needs [58,59].

External factors, such as government policies and the prevalent use of top-down approaches in decision-making processes, have limited the effectiveness of interventions on 
community-managed forests $[48,60]$. In addition, most of the landscape restoration efforts are biased towards conserving biodiversity and have paid little attention to the identification of the views and priorities of local communities towards forest conservation [61]. For instance, inadequate involvement of communities and poorly defined goals constrained the state and NGO-led efforts to rehabilitate degraded forests [47]. Such constraints affected the sense of ownership of rural communities over the forests and aggravated tenure insecurity $[62,63]$.

Failing to address governance challenges in time could undermine the increased investment in forest and landscape restoration measures at sub-national and national levels. For instance, the implementation of the Climate Resilient Green Economy (CRGE) strategy relies on the sustainable governance of forest resources by rural communities. Ethiopia's commitment to rehabilitate 15 million hectares of degraded landscape under the AFR100 program could depend on the adequacy of attention to the governance of communitymanaged forests [60]. The same holds true for the success of the "green legacy", a recent initiative led by high-level political leaders which proclaimed the planting of more than 350 million seedlings in one day in 2019 (World Economic Forum, 31 July 2019). Rural communities have a central role in sustaining the efforts, and this makes analysis of the requirements for improved forest governance in community-managed forests an important research task.

Past research in Ethiopia has focused on generating evidence on the changes in forest cover, soil fertility, and carbon sequestration following the implementation of communitymanaged forests [64-67]. Some evidence exists for the socio-economic benefits and ecosystem services of community-managed forests [59,62,68-70]. Biophysical and governancerelated factors determined the success of community-managed forests [71]. A few studies also analyzed issues related to governance in community-managed forests [52,56,72-75]. However, evidence concerning the requirements for improving governance in communitymanaged forests to inform on-going and upcoming investments is lacking. Therefore, this paper attempts to review and synthesize the evidence on governance constraints with the aim of identifying the requirements to improve governance in community-managed forests.

The rest of the paper is organized as follows. The next section provides an overview of the methods. The third section discusses the factors affecting governance of communitymanaged forests, with a focus on participation, accountability, equity, representation, direction and vision, and performance aspects. The fourth section considers the requirements to improve governance in community-managed forests. The last section presents the conclusions, along with recommendations for policy and practices.

\section{Methods of the Literature Review}

Data was collected using computerized searches of online databases, including science direct and Scopus, from June-December 2019. More than 60 journal articles published in the past two decades were reviewed using the guidelines suggesting how to search, collect, and organize literature [76]. The terms used to search for literature separately and in combination included: 'communal forests', 'community forests', 'community-managed forests', 'exclosures', 'church forests', 'community woodlots', 'dryland forests', 'hillsides', 'land restoration', 'forest rehabilitation', 'PFM', 'governance', 'forest management', 'participation', 'inclusiveness', 'decision-making processes', 'ownership', 'accountability', ' 'representation', 'transparency', 'equity', 'gender equity', 'marginalized groups', 'women', 'youth', 'performance', 'rural livelihoods', and 'forest dependence'.

The initial screening resulted in more than 300 articles. Further screening of the articles was employed using the criterion peer-reviewed articles published during 2000 and 2020 with a focus on the governance aspects of community-managed forests. Articles which provided overviews on concepts of forest governance and articles on historical and policy aspects of community-managed forests were included to strengthen the argument of the paper. The reviewed articles employed diverse methodologies, including quantitative and qualitative approaches, yet focused on governance issues of community-managed forests 
in Ethiopia. Deductive coding was conducted using themes such as governance-related constraints (vision, participation, accountability, equity, and performance) and required incentives to address the constraints.

\section{Factors Affecting Governance of Community-Managed Forests}

This section elaborates on the challenges in community-managed forests in Ethiopia with regard to key governance elements: participation, accountability, equity, representation, direction and vision, and performance.

\subsection{Participation}

A diverse set of factors influence the types and levels of participation in communitymanaged forests (Table 1). Participation was inconsistent across stages of implementation of development interventions, i.e., from initiation of interventions to monitoring and evaluation of outcomes [77]. There was no mention of a project initiated and designed by or with involvement of the local communities in the reviewed literature, indicating that design and planning phases of projects exhibited top-down approaches [78-80]. Government authorities and NGOs start to seek participation of local communities during site identification and demarcation of forest boundaries $[44,81]$. There are two possible reasons for this early phase of participation.

First, the insecurity over land tenure makes it mandatory for non-local actors to show some level of sensitiveness and seek the consent of local communities in the planned interventions. Otherwise, the fear of losing land could trigger suspicion and resistance among local communities. Second, participation, regardless of its forms and intensity, has become a norm in development interventions for purposes of getting the 'buy in' of local communities for mere reporting purposes.

In either case, external bodies use their authority to decide on how the local communities should participate in the interventions. External bodies often prefer consultation, a somewhat passive form of participation, which involves seeking public opinion on the interventions they have already designed and/or inviting participation of local communities in the planned activities [26]. Consultation in its various forms, including onetime public meetings or general surveys on the pre-specified problems, has been the preferred form of participation.

In addition, development practitioners face a dilemma about getting effective institutional arrangements to manage and utilize the rights of forest management, while, in some areas, interventions either endorsed the use of village bylaws and religious values or at least attempted to align local institutions and formal institutions [52,54,73]. However, most of the literature reported a top-down approach, in which external actors impose their version of well-functioning institutional arrangements on local communities by intervening during the establishment of bylaws [63]. A common trend in southern and southwestern parts of Ethiopia is establishing forest user cooperatives mainly for the ease of mobilizing collective action for forest protection, management, and benefit sharing [70,82,83]. However, this shift has demolished local institutions which had been well-embedded in the socio-cultural lives of the local communities and missed the chance to integrate local knowledge into the bylaws [84,85]. The slight flexibility of the formal institutions could also further deprive the poor and marginalized groups of their forest-based incomes and livelihoods [86,87].

The reviewed literature also revealed minimal levels of participation in monitoring and evaluation phases $[88,89]$. This could be attributed to the lack of a thorough framework for conducting sound monitoring and evaluation of community-managed forests. Oftentimes, extension personnel provided little or no technical tools and support to local communities during monitoring. The level of monitoring in community-managed forests is often limited to rough estimates on progress, achievements, and outcomes. This limitation had made it difficult to draw lessons from weaknesses in the governance systems and make timely adjustments. 
However, a relatively higher level of participation of local communities was observed during implementation phases compared to the planning and monitoring and evaluation phases [56,79]. This could be attributed to the growing use of bottom-up approaches during implementation which increase the space for participation of local communities in deciding how forests should be protected, managed, and utilized. Regardless of this, the implementation process was characterized by low levels of rule enforcement. The situation could emanate from the discouragement of the previous social sanctions and norms the local communities used to enforce rules on community-managed forests. It also contradicts the fact that participation in social institutions was observed to motivate forest users to play active roles in community-managed forests [90].

Heavy dependence on forests was also found to have a positive influence on participation during the implementation phase [91]. Nevertheless, women were not given space to negotiate their priorities and interests during the 'bottom-up' approaches regardless of their heavy dependence on forests [87]. In addition, the approach was not strong enough to protect the decision-making processes from manipulation by elites to favor their own interests, elite capture in the village committees representing farmers in rural villages of Tigray [92]. The selection of village committee members often favors rich farmers who are better-off in terms of livelihood assets, including land and oxen, those with strong ties to the local political leadership, and those with good public-speaking skills [93]. Elites could influence decision-making processes due to their access to information from different sides and to formal and informal decision-making platforms, including informal get-togethers, and their ability in lobbying for their own interests $[59,94]$. Furthermore, the little attention given to address tenure insecurity could also affect the commitment of forest users to follow the rules [95].

Table 1. Factors affecting forest governance of community-managed forests.

\begin{tabular}{|c|c|c|c|}
\hline Elements & Factors Affecting Governance & Outcome & Sources \\
\hline \multirow{13}{*}{ Participation } & Collective action during demarcation of boundaries & + & \multirow{13}{*}[78,79,81,91,95]{} \\
\hline & Consideration of local context during planning & + & \\
\hline & High level of community participation at implementation phase & + & \\
\hline & $\begin{array}{l}\text { Local communities are not involved in the formulation of } \\
\text { forest legislation }\end{array}$ & - & \\
\hline & $\begin{array}{l}\text { Low community participation during design, planning, and } \\
\text { monitoring and evaluation phases }\end{array}$ & - & \\
\hline & Government and NGOs intervening in establishing bylaws & - & \\
\hline & Combination of formal and informal institutions & + & \\
\hline & Organizing forest users under cooperatives & + & \\
\hline & Low participation of women in decision-making processes & - & \\
\hline & High level of dependence on forest for income & + & \\
\hline & Participation in social institutions & + & \\
\hline & Limited support of extension personnel & - & \\
\hline & Tenure insecurity on community-managed forests & - & \\
\hline \multirow{5}{*}{ Accountability } & Local community setting up own bylaws & + & \multirow{5}{*}[89,96-99]{} \\
\hline & Moving decision-making power away from the grassroots & - & \\
\hline & Election of forest committees and guards in a general assembly & + & \\
\hline & Elite capture of decision-making processes & - & \\
\hline & $\begin{array}{l}\text { Limited awareness of the content of formal agreements signed by } \\
\text { the communities }\end{array}$ & - & \\
\hline
\end{tabular}


Table 1. Cont.

\begin{tabular}{|c|c|c|c|}
\hline Elements & Factors Affecting Governance & Outcome & Sources \\
\hline & Low level of rule enforcement using bottom-up approach & - & \\
\hline & $\begin{array}{l}\text { Guards have the right to take offenders to the village judiciary or } \\
\text { general assembly }\end{array}$ & + & \\
\hline & Low level of awareness of community's rights on forests & - & \\
\hline & $\begin{array}{l}\text { Mutual trust and understanding among local community and } \\
\text { external actors }\end{array}$ & + & \\
\hline & $\begin{array}{l}\text { Empowering local community with knowledge and technologies to } \\
\text { manage forests better }\end{array}$ & + & \\
\hline & Strengthening capacities of institutions and partnerships among actors & + & \\
\hline & Issuance of land titles for community-managed forests & + & \\
\hline & $\begin{array}{l}\text { Data inaccuracy and mere focus on area coverage of interventions } \\
\text { in reporting }\end{array}$ & - & \\
\hline & $\begin{array}{l}\text { Politicization of governance of community-managed forests by } \\
\text { local authorities }\end{array}$ & - & \\
\hline & Little horizontal accountability among actors & - & \\
\hline & Use of short-term benefits to buy trust & + & \\
\hline & Limited technical support of higher-level government & - & \\
\hline & Lack of clear management guidelines & - & \\
\hline \multirow{18}{*}{ Equity } & Lack of access to forests by marginalized groups & - & \multirow{18}{*}[61,100-103]{} \\
\hline & Livelihood improvement interventions & + & \\
\hline & Unequal distribution of services and disservices among forest users & - & \\
\hline & $\begin{array}{l}\text { Quota system to use grass and allowing timber harvest for construction } \\
\text { of public facilities }\end{array}$ & + & \\
\hline & Allocation of grass based on livestock ownership & - & \\
\hline & Low fines compared to market prices favoring better-off members & - & \\
\hline & $\begin{array}{l}\text { Better-off members provide low payments for grass and take } \\
\text { advantage of the poor members' quotas }\end{array}$ & - & \\
\hline & Low level of interest in community-managed forests among the youth & - & \\
\hline & Scarcity of grazing areas discourages ownership of bigger herds & - & \\
\hline & $\begin{array}{l}\text { Forest users residing farther from the forest earn lesser } \\
\text { economic returns }\end{array}$ & - & \\
\hline & Limited access to non-farm employment opportunities & - & \\
\hline & $\begin{array}{l}\text { Increased harvest of forest products to address income gaps of } \\
\text { poor households }\end{array}$ & - & \\
\hline & $\begin{array}{l}\text { Inequity in forest dependence and income generation from forest } \\
\text { products among households }\end{array}$ & - & \\
\hline & Inequity in power relations among forest users & - & \\
\hline & $\begin{array}{l}\text { Flexibility in considering requests of individuals constructing houses to } \\
\text { use timber and grass thatching }\end{array}$ & + & \\
\hline & $\begin{array}{l}\text { Corruption of village committee and guards through bribes, and } \\
\text { favoring own relatives and friends }\end{array}$ & - & \\
\hline & $\begin{array}{l}\text { Interventions on diversifying the livelihoods of the poor and } \\
\text { forest-dependent members }\end{array}$ & + & \\
\hline & Use of monetary and social sanctions for rule enforcement & + & \\
\hline
\end{tabular}


Table 1. Cont.

\begin{tabular}{|c|c|c|c|}
\hline Elements & Factors Affecting Governance & Outcome & Sources \\
\hline \multirow{12}{*}{ Representation } & Recognition of community and indigenous usufruct rights over forests & + & \multirow{12}{*}[85,104-107]{} \\
\hline & Forest management committees inclusive of actors at sub-village level & + & \\
\hline & Male dominance of leadership in forest user groups & - & \\
\hline & Decreased legitimacy of traditional forest governance systems & - & \\
\hline & Failure to represent diverse social groups in forest user committees & - & \\
\hline & $\begin{array}{l}\text { Interference of NGOs and government in selecting representatives of } \\
\text { local communities }\end{array}$ & - & \\
\hline & Embeddedness of governance structures within socio-cultural context & + & \\
\hline & Imposition of outside rules for managing forests & - & \\
\hline & $\begin{array}{l}\text { Community representatives' use of their positions to promote own } \\
\text { views and expectations }\end{array}$ & - & \\
\hline & Clarity of roles, functions, and timelines of leadership of forest groups & + & \\
\hline & $\begin{array}{l}\text { Limiting membership of forest user groups based on proximity } \\
\text { to forests }\end{array}$ & - & \\
\hline & $\begin{array}{l}\text { Neglect of heterogeneous and fragmented interests of forest } \\
\text { user groups }\end{array}$ & - & \\
\hline \multirow{17}{*}{ Direction and Vision } & Communal goals and shared visions among forest users & + & \multirow{17}{*}[47,51,108-110]{} \\
\hline & Use of highly devolved structures of community-managed forests & + & \\
\hline & $\begin{array}{l}\text { Establishment of rules to manage formerly "open access" forests by } \\
\text { local communities }\end{array}$ & + & \\
\hline & Capturing the felt priorities and needs of local communities & + & \\
\hline & $\begin{array}{l}\text { Empowerment of local communities to manage forests with some } \\
\text { technical support }\end{array}$ & + & \\
\hline & $\begin{array}{l}\text { Unmet expectations of local communities over economic benefits } \\
\text { of forests }\end{array}$ & - & \\
\hline & Limited availability and access of alternative energy sources & - & \\
\hline & Little effort made towards reducing forest-dependent livelihoods & - & \\
\hline & $\begin{array}{l}\text { Weak government institutions to support and monitor management of } \\
\text { community-managed forests }\end{array}$ & - & \\
\hline & $\begin{array}{l}\text { Establishment of new forest user groups and forest management } \\
\text { guidelines by external actors }\end{array}$ & - & \\
\hline & Recognition of local knowledge in forest management interventions & + & \\
\hline & $\begin{array}{l}\text { Lack of land use policy and strategies to guide management of } \\
\text { community-managed forests }\end{array}$ & - & \\
\hline & Limited efforts to engage private sector in community-managed forests & - & \\
\hline & $\begin{array}{l}\text { Little effort made to increase productivity of community-managed } \\
\text { forests }\end{array}$ & - & \\
\hline & $\begin{array}{l}\text { Inconsistency of promotions and campaigns in rehabilitation of } \\
\text { communal degraded forests }\end{array}$ & - & \\
\hline & $\begin{array}{l}\text { Lack of innovative approaches to increase revenue from } \\
\text { community-managed forests }\end{array}$ & - & \\
\hline & Communal goals and shared visions among forest users & + & \\
\hline
\end{tabular}


Table 1. Cont.

\begin{tabular}{|c|c|c|c|}
\hline Elements & Factors Affecting Governance & Outcome & Sources \\
\hline \multirow{13}{*}{ Performance } & $\begin{array}{l}\text { Reduced deforestation and increased forest status through } \\
\text { collaborative forest management }\end{array}$ & + & \multirow{13}{*}[84,111-114]{} \\
\hline & $\begin{array}{l}\text { Increased conflicts among forest users and non-forest user groups over } \\
\text { forest use }\end{array}$ & - & \\
\hline & Improved market linkages for non-timber forest products & + & \\
\hline & $\begin{array}{l}\text { Limited success in narrowing the income inequity among better-off } \\
\text { and poor members of community }\end{array}$ & - & \\
\hline & $\begin{array}{l}\text { Improved livelihoods from income diversification activities in } \\
\text { community-managed forests }\end{array}$ & + & \\
\hline & $\begin{array}{l}\text { Little effort made to address the gender gap in planning, } \\
\text { implementation, and monitoring }\end{array}$ & - & \\
\hline & Low level of knowledge management and monitoring activities & - & \\
\hline & $\begin{array}{l}\text { Weak institutional settings due to disregard of pre-existing institutions } \\
\text { and imposition of 'new' ones }\end{array}$ & - & \\
\hline & $\begin{array}{l}\text { Capacity development interventions improved human capital of forest } \\
\text { user groups }\end{array}$ & + & \\
\hline & $\begin{array}{l}\text { Livelihood interventions with little attention to local priorities and } \\
\text { ownership of forest user groups }\end{array}$ & - & \\
\hline & $\begin{array}{l}\text { Mistrust among local community as government interferes in decision } \\
\text { making on forest revenue }\end{array}$ & - & \\
\hline & Restrictions on harvesting forest products for commercial purposes & + & \\
\hline & Lack of short-term economic incentives & - & \\
\hline
\end{tabular}

Note: + sign indicates positive outcome; - sign indicates negative outcome.

\subsection{Accountability}

Accountability in community-managed forests differed across cases, yet there is a consensus among authors on the widespread lack of accountability in decision-making processes [96,115-117]. Quite often, the decisions made in the inception phase lacked accountability. The design and planning phases attempted to show some level of accountability by allowing local communities to elect leadership committees and guards in a general assembly. At this phase, external bodies invest their time and resources in building trust and mutual understanding among local communities [96,97]. In some cases, short-term economic benefits contributed to building trust and to improving collaboration among local communities and external bodies. Attention was also given to strengthening the capacities of institutions that manage community-managed forests through training and provision of technical support [51].

Positive outcomes, such as increased awareness of the need to protect and restore degraded forests and having shared goals among local communities, were observed. Interventions in empowering local communities with knowledge and technologies improved the level of accountability [96]. However, there was a low level of accountability among higher level governing bodies. This can be observed in the lack of involvement of local communities in the formulation of forest legislation and in the limited technical support provided by higher level experts [99]. Decision-making processes in legal and policy frameworks have not provided space to allow negotiations and platforms to capture the interests of forest users.

The administrative framework assumed that weredas would serve as implementing agencies with minimal power to draft legislation which considers the local context under which the community-managed forests are governed. This top-down approach reduced the decision-making power of actors at grassroots level [48,57]. These limitations coupled 
with the lack of guidelines to indicate optimal approaches to community-managed forests resulted in minimal levels of accountability.

Limited efforts were underway to improve accountability during the implementation of community-managed forests. This could be associated with the assumption of the government and NGOs that the leadership of forest user groups would be accountable to local communities [52]. However, several cases confirmed that the forest management committees were more accountable to external actors than to local communities $[89,97,116]$. The quality of leadership and the emphasis given to equality and efficiency also influenced rule enforcement in community-managed forests [117].

Furthermore, the bypassing of local institutions and the establishment of forest group cooperatives resulted in low levels of accountability, as local communities claimed that they were not aware of the contents of the signed formal agreements. This condition is aggravated by the uncertainty of the rights of local communities over forests. Some attempts were made to improve tenure security by issuing land titles for communitymanaged forests $[96,118]$. However, state ownership of land creates ambiguity in practicing usufruct rights, such as the safe level of investment in community-managed forests by local communities.

By and large, governance structures, including the leadership of forest groups and guards, were expected to report to village assemblies. In most instances, guards enforce rules and have the right to take offenders to the village judiciary or general assembly [52]. The arrangement seemed to enhance accountability to a certain extent. However, the assembly could also fail to make the leadership accountable in cases of elite capture, which leaves the local communities with little room to claim their rights. In certain cases, there was a tendency to use the general assembly to get approval for decisions that were already made informally by the forest management committees.

The minimal level of accountability has been observed at monitoring and evaluation phases of community-managed forests. Oftentimes, the inaccuracy of data and information and the mere focus on area coverage of interventions left accountability at a minimum [89]. The low capacity of local level actors made it difficult to conduct sound monitoring of the interventions. Once more, the increased attention given to area coverage during tree planting and afforestation campaigns by political leaders at higher levels contributed to exaggerated reporting on the side of the extension personnel and authorities at local levels. Such politicization of efforts coupled with the low level of horizontal accountability among actors weakened accountability in community-managed forests.

\subsection{Equity}

Efforts towards achieving equity in community-managed forests resulted in mixed outcomes. Success was observed in cases where livelihood and non-forest income-generating activities were integrated in the governance of community-managed forests [91,111]. For instance, social protection schemes (in the form of cash or food) were used to compensate farmers for their contributions to collective action. Apiculture was also a commonly promoted livelihood intervention in community-managed forests, though its contribution to income and livelihoods depends on access to markets $[100,103]$ and the number of beehives given to individuals or organized groups [119]. Such interventions resulted in positive outcomes in terms of income and livelihood improvements among the forest user groups [83]. However, the external actors' use of their authority to decide on the interventions without seeking input from the local communities regarding the acceptability, the conducting of environmental suitability analyses, and the testing of the economic viability of the activities limited the outcomes $[57,109,119]$.

The flexibility in enabling grass and timber use for public purposes and special occasions had also motivated forest users to actively engage in collective action [61]. However, equity was minimal in several instances due to the inadequacy of benefit-sharing mechanisms [120]. Forest users with different levels of power, wealth status, and dependence on forest products were differently affected by the governance of the forests $[102,103]$. The gov- 
ernance system indirectly helped the rich get richer but made the poor get poorer. The commonly used approach to allocate grass based on livestock ownership also favored the betteroff farmers that owned larger herds and engaged in bull-fattening businesses [100,102]. The increased market prices for forest products also stimulated the corruption of the forest committees and guards, not only through bribes but also by enabling selective rule enforcement which favored their relatives [52].

In addition, exclusion of the poor and marginalized members of the community was prevalent across cases $[101,103]$. This is unfortunate in that such groups often relied on forest resources for their income and livelihoods, as they engaged in firewood collection and charcoal making. In some cases, a special consideration for the groups in the village bylaws protected them from total exclusion. For instance, in several parts of northern Ethiopia, the poorest members of the community were identified and given approval by the general assembly to collect dry and dead wood for sale [52,59]. Some efforts also focused on the distribution of degraded hillsides so that landless youth could rehabilitate and use the land for income-generating activities as an attempt to address the inequity among local communities [121]. However, in some areas where forest user groups were organized under cooperatives, there was little room for flexibility to consider the marginalized groups, such as the landless youth $[53,87]$.

Inequity was also observed in the sharing of risks and distribution of benefits and services [101]. This condition created groups of communities who were affected negatively and forced to risk their livelihoods in the name of benefiting equally with the rest of the community. In many instances, rural communities had limited access to non-farm employment opportunities. In such cases, the establishment of community-managed forests could mean less availability of land to be used for crop production and less opportunity to engage in farming $[67,68]$.

In such cases, community-managed forests could have unintended outcomes in aggravating unemployment and putting a group of community members at greater risk of inequity. There was bias in the interventions favoring forest users living in proximity to the forest compared to those living farther away, often with the assumption that those living farther away might contribute less to collective action than others [78,103]. Moreover, the scarcity of grazing land following the establishment of community-managed forests coupled with the low levels of adoption of zero-grazing practices negatively affected forest users who owned large herds of livestock [102].

\subsection{Representation}

Several factors contributed to the limited representation in community-managed forests regarding rights, voices, and cooperation [105,106]. Attempts to consider the community and indigenous usufruct rights over forests brought positive outcomes in terms of improved sense of ownership and reduced conflicts over the use of forests [105]. Such consideration proved critical as not all usufruct rights had formal shape or were legally protected. Unfortunately, this has not been the case in most instances, as interventions undermined the legitimacy of the traditional forest governance systems [74,85].

The norm for interventions has been to establish new governance structures rather than building up existing institutional arrangements. Project staff tended to emphasize the need to change the institutional context and start afresh and struggle to find a way of integrating the existing institutions in the new arrangements $[57,122]$. The lack of balance regarding what to retain from the existing systems and what to add as new or improved into the governance system revealed weaknesses during design and planning phases.

In addition, questions of representation emerged on the criteria used for membership and leadership of forest user groups. Membership in forest user groups and engagement in leadership positions were limited to villagers who live near the forests. Little or no representation was reported for those living farther away. This approach exhibited unfairness and affected cohesiveness and cooperation among local communities. The measure also 
discouraged cooperation and failed to take into consideration the interconnected nature of resources within and across landscapes.

In some cases, the local communities preferred an open access situation where they were not denied their rights to use the forest compared to a community-managed forest where their voices and rights were not represented, [78,89]. The community-managed forest projects often failed to devise mechanisms to capture the voices of the "non-beneficiaries" [104,106]. At times, interventions have favored the welfare improvement of better-off farmers over poor farmers [123]. In such cases, all the efforts put into the projects could be of no value to a part of the local communities and this makes achieving sustainability implausible.

Additionally, the forest user groups revealed heterogeneity in terms of family size, assets, labour availability, and dependence on forests for income and livelihoods, among other factors. In some instances, attempts were made to cover the heterogeneity by ensuring that forest user committees involved representatives from sub-villages [107]. The common approach, however, has been to assign leaders in a general assembly. This approach allows for an 'invisible' hierarchy within the society which enables the influential members to take up leadership roles. This could in turn lead to a leadership with skewed interests. Representation in forest user committees also did not consider the diversity in social groups, including gender and economic status [104]. Poorly represented leadership might fail to promote the interests and voices of the poor and marginalized groups, such as landless youth and women [52,53]. Thus, the inability to acknowledge the diversity among social groups contributed to the weakness of incentive mechanisms which would get the buy in of the forest users.

\subsection{Direction and Vision}

Expansion of community-managed forests was promoted as an important cornerstone to realize the CRGE strategy. The government showed interest in restoring degraded forests and increasing the area covered by forests as pillars of its target to promote a green economy $[47,51]$. The shift led to a wider level of expansion of exclosures and also gave a formal shape to the management of community-managed forests [108]. However, there was variation in the way the direction and vision were interpreted, especially when it came to duration and expectations of what would come afterwards [110]. This could be attributed to the lack of land use policies and strategies to guide the management of communitymanaged forests at a country level [108]. The differences in experience of governance of community-managed forests across the country also contributes to the inconsistency in shared visions.

Attempts to capture the felt priorities and needs of local communities were successful in mobilizing forest users to pursue shared goals [44,51]. Among other factors, the use of highly devolved structures to mobilize local communities also helped to reduce hesitation in local communities and encouraged them to accept the shift from centralized approaches to managing forests at the community level [107]. The reform enables local communities to establish their own rules for managing forests and has resulted in positive outcomes in terms of empowering local communities and increasing the sense of ownership [52,108]. Even so, the replacement of pre-existing institutional arrangements with new forest user groups coupled with external actors putting forest management guidelines in place contradicted the efforts to empower and recognize local knowledge in forest management interventions [101].

The limited availability and accessibility of alternative energy sources forced forest users to act against their shared vision. However, there was inadequate exploration of innovative approaches for increasing revenue from community-managed forests and addressing the demands for economic incentives in the short, medium, and long terms [119]. For instance, the expansion of exclosures was accompanied by dissatisfaction and unmet expectations to gain economic incentives among local communities. However, government institutions had a limited capacity to monitor and align the community-managed forests with the direction and shared visions [108]. 
Furthermore, little effort was made to reduce the level of dependency on forests for income and livelihoods relative to the extent of the problem [91,100]. The engagement of the private sector in increasing forest productivity and the adoption of efficient technologies and approaches, along with exploitation of the potential of community-managed forests for employment opportunities, is weak at best compared to the goals set out in the forest policies at national and regional levels and in the national CRGE strategy.

\subsection{Performance}

Several factors influenced the performance of community-managed forests in achieving their goals of establishment [84,111-114]. For instance, factors including user groups' heterogeneity, level of forest dependence, and distance to town influenced the performance of community-managed forests in southern Ethiopia [113]. One of the well-recognized outcomes of community-managed forests was the impact in reducing deforestation and improved forest status [51,114]. The outcomes were attributed to the improved knowledge and skills among forest users due to the capacity development interventions to a certain extent [124].

Interventions revealed biases towards climate change adaptation and mitigation and biodiversity conservation goals, and these goals were almost exclusively prioritized in evaluations of the performance of community-managed forests [112]. The mere focus on ecological improvement (change in forest cover, availability of diverse woody species) in evaluating performance and neglect of socio-economic indicators in most cases limited the contribution of community-managed forests to improving incomes and livelihoods [88,103,109].

Recent approaches that integrate mechanisms for livelihood diversification activities in community-managed forests were successful in improving rural livelihoods. However, the success was limited due to insufficient consideration given to local priorities and ownership of forest user groups in the livelihood interventions [98]. In addition, the initiatives were lacking when it came to mediating increased conflicts among forest users and non-forest user groups over forest use [125].

Interventions also failed to narrow inequity among different gender and wealth groups in terms of access to and control over decision-making processes in planning, implementation, and monitoring phases [84]. Among other issues, the restrictions on harvesting forest products for commercial purposes without putting in place short-term economic incentives limited the performance of community-managed forests. In this line, the inadequacy of the indicators and tools used to assess the performance of community-managed forests also constrained the efforts to develop sound management guidelines and business plans for proper utilization of the forests.

\section{Requirements to Address Key Governance Constraints in Community-Managed Forests}

The complex challenges related to governance of community-managed forests would require multi-dimensional measures implemented in a coherent manner. First, constraints on participation could be addressed by engaging the local community at the outset of interventions and continuing the partnership till the monitoring and evaluation phases. Twelve out of the 60 articles suggest that interventions need to recognize inputs from forest users using continuous feedback mechanisms and keep the momentum in partnership with forest users at all phases. This would help in addressing the decline in participation at the planning, and monitoring and evaluation phases of the interventions. Emphasis should also be given to the diversity of forest management committees. Ensuring the balance in representation of different social categories and actors in leadership positions would capture the diverse voices and interests.

Establishing homogenous subgroups (i.e., sharing similar backgrounds, interests, and priorities) for community-managed forests would also help in reducing dominance by elites in decision-making processes. Recent studies revealed that multi-stakeholder forums could potentially help in capturing the concerns of forest users and joint working towards solving 
problems. Establishing and supporting such forums at grassroots level proved effective in cases where mechanisms were put in place to addressing elite capture, promoting inclusiveness and developing the capacities of forest users in problem identification and implementation. Forums also help in reducing elite capture by enhancing transparency and accountability in decision-making processes $[53,126]$.

Such requirements might motivate stakeholders to go beyond the usual consultations and make progress towards the next level of participation (i.e., partnerships which involve redistribution of power among the actors through negotiation), as suggested by [26]. However, it is important to note that the requirements might not lead to positive outcomes unless they are accompanied by determination and attitude change among external actors in contrast to the practice of using participation and representation as mere rituals in development. The willingness of actors to negotiate and redistribute power amongst themselves would be a critical step to achieve the desired outcomes. Among other measures, carrying out a thorough analysis of the socio-cultural context prior to deciding who should participate in the interventions would help in managing competing interests and reducing conflicts [127].

Second, the dilemma in balancing formal vs. informal institutions could be resolved by prioritizing and recognizing the pre-existing institutions. Fifteen out of the 60 articles suggest that implementing agencies should encourage the use of informal institutions if available or encourage forest users to build their own bylaws in case there are no preexisting institutions in place. Then, supporting forest users to jointly discuss the bylaws and eventually explore the right combination of elements of formal and informal institutions for governing the community-managed forests would help resolve the dilemma.

In fact, enforcing these requirements might lead to difficulties due to the dynamic nature of both formal and informal institutions as they respond to the past and ongoing changes in the society and the management of forest resources. Historically, the state assumed a custodial position which allowed it to control forest resources in the jurisdiction and weakened the contribution of informal institutions which governed communal forests in the past [35]. The little recognition given to empowering the informal institutions and the unparalleled interest in embracing modern forms of governance weakened the informal institutions [128]. The newly introduced institutions also faced difficulties in building a sense of ownership of community-managed forests [34,73].

Nine out of the 60 articles showed that the situation has left a politicized institutional context with a delicate nature. For that reason, it is important to devise mechanisms to engage local communities in the design and planning of interventions while limiting the engagement of government actors to legitimize and empower the institutions $[129,130]$. Thus, interventions should be designed with due understanding of the institutional changes in specific contexts and identify mechanisms to develop a hybrid of institutions to address governance constraints in community-managed forests [55]. In addition, the establishment of multi-stakeholder forums with due consideration of the existing formal and informal institutions in the design and implementation of management systems could help in addressing the institutional constraints. In fact, multi-stakeholder forums could play important roles in governing community-managed forests in Ethiopia when embracing a mix of top-down and bottom-up approaches for increased alignment and impact of the interventions in community-managed forests [53].

Third, using well-tailored capacity development interventions could enable forest users to improve governance of community-managed forests. Aligning capacity development efforts with local needs and priorities would help in using the scare resources more efficiently. Working with forest users to develop the curricula would help to tailor capacity development with local needs and priorities with due consideration to the socio-cultural contexts. The use of both formal and informal networks for communication would equip women, youth, and other marginalized forest users with minimal access to the formal decision-making processes with relevant knowledge and information. 
Enforcing these requirements might be misinterpreted as just performing more of the same capacity-development interventions. However, efforts in the past missed the chance to genuinely empower local communities and the institutions they rely on to sustainably govern community-managed forests. Thus, the requirements call for more attention to interactions and power relations among the stakeholders. In addition, emphasis should be placed on building the 'soft' skills that would enhance the confidence of local communities to exercise their power in decision-making processes and rule enforcement [131].

Fourth, locally contextualized management plans that include benefit sharing schemes in the short, medium, and long terms would help forest users develop realistic expectations and benefit from community-managed forests. Consideration should be given to establishing benefit-sharing mechanisms based on local interests and ensure mutual understanding of the expected benefits and timelines. In particular, devising mechanisms for short-term benefits would be critical to motivate forest users. Once more, developing easy-to-use forest management guidelines in collaboration with forest users would help increase the productivity of community-managed forests.

Developing business plans that consider forest users' needs and priorities and provide diverse and locally contextualized incentives would help meet the interests of heterogeneous groups of forest users. For instance, encouraging youth engagement in non-timber forest products would also create economic opportunities for forest users. Additionally, livestock owners could be motivated by increased access to grass for fodder, while those who do not own livestock might prefer incentives in the forms of finance or credits or employment opportunities. Exploring mechanisms for engaging non-forest users, for instance, through investment in social amenities, would also reduce conflicts over forest use.

Once more, exploring opportunities for upgrading forest value chains would be central to realizing increased socio-economic benefits of community-managed forests. Often, the lack of alternative livelihoods and the need to use the forest for survival reasons has been the source of conflict in the governance of community-managed forests. Interventions could target upgrading the products and services of community-managed forests to address the conflicts and protect the livelihoods of the poor and forest-dependent communities.

Fifth, supporting non-forest-based livelihoods and investing in attitudinal change towards considering community-managed forests as business enterprises would help forest users to visualize goals and streamline their expectations accordingly. More than $50 \%$ of the reviewed articles emphasize the need for incentives which reduce dependence on forests, including providing women with alternative energy sources (introducing solar energy), providing energy-conserving stoves, and establishing homestead nurseries to cultivate high-value tree species (fruit trees) for income generation and employment among youth and women.

Sixth, attention should be given to examining the reasons leading to limited success in the efforts to improve governance of forests. This requirement calls for revisiting the government's use of the campaign approach in implementing forest policies due to its inconsistent and seasonal nature, and limited effect in improving governance of communitymanaged forests. The approach failed in addressing conflicts related to land tenure, access to and control over forests, and alternative livelihoods.

Oftentimes, local communities have taken the blame for increased deforestation and forest degradation due to their proximity to the forests and their dependence on the forests for their livelihoods [132]. However, government actors need to examine their contributions to the successes and failures in the governance of community-managed forests and work towards creating an enabling environment accordingly. The development actors need to demonstrate their commitment and willingness to create an enabling environment by pushing for governance of community-managed forests agendas in policy reforms.

\section{Implications for Forest and Landscape Restoration}

The Bonn Challenge aims at restoring 350 million hectares of degraded and deforested landscapes globally by 2030. Consequently, commitments have been made to restoring 
over 140 million ha of land across the tropical region [133]. Such commitments would be realized when governance systems in the forestry sector enable the implementation of landscape restoration at low transaction costs [134]. Landscape restoration has focused on the promotion of community-managed forests and led to promises for compensation of communities' efforts through incentive mechanisms, such as carbon financing through Deforestation and Forest Degradation (REDD+) schemes [135]. The need for guidance on the promotion of cost-effective mechanisms has been emphasized for achieving desirable outcomes with respect to socio-ecological conditions. Restoration of degraded landscapes is among the priority areas for ensuring food security and improvement in livelihoods in Ethiopia [51]. Efforts are underway in promoting PFM and multi-stakeholder forums for improved governance of community-managed forests [108]. For instance, multi-stakeholder forums in the Bale Eco-region, Ethiopia were successful in enhancing good governance in community-managed forests through active engagement of relevant government departments at wereda level (agriculture, natural resources management, irrigation and livestock), and other stakeholders, including PFM cooperatives, NGOs operating in the eco-region, and OFWE. The multi-stakeholder forums were established at wereda levels with active involvement of PFM cooperatives at the local level in problem identification and implementation. The collaboration resulted in evidence-based decision making, improved local capacity and joint learning, increased fairness in benefit sharing, efficient mobilization and use of resources, and reduced duplication of efforts in community-managed forests [53]. Such forums, accompanied with participatory monitoring systems in place for measuring outcomes, would help in achieving good governance in community-managed forests.

Prior experience has shown that such efforts would succeed with and only if attention is given to the local context and with due understanding of the enabling and constraining factors for sustainable governance of community-managed forests. Understanding the governance requirements is critical for the implementation of the forest and landscape restoration initiatives at low transaction costs. Initiatives should pay attention to understanding the diverse institutional arrangements under which community-managed forests are governed for increased impact and sustainability of positive outcomes. Our findings indicate the central role of collaboration among stakeholders and the urgent need to address the governance constraints in participation, accountability, equity, representation, direction and vision, and performance aspects, which could lead to better forest conditions and livelihood outcomes. The lessons can also be scaled up to reduce the pollution of waterbodies, such as rivers and lakes in highly populated rural and urban areas of Ethiopia through managing forest resources surrounding riverbanks and buffer zones. The identified governance requirements contribute to filling the gap in evidential syntheses to inform decision-making processes in forest and landscape restoration initiatives in Ethiopia. Additionally, the findings have implications for setting priorities in the initiatives.

\section{Conclusions}

This review shows the urgent need for addressing governance constraints in communitymanaged forests. The design and implementation of the initiatives in addressing deforestation and forest degradation should pay attention to the active involvement of forest users at all stages of managing community-managed forests and capacity-development programs. Building on existing informal institutions would help to address the dilemma in balancing the roles of informal vs. formal institutions in managing community-managed forests. Supporting non-forest-based livelihoods and investing in attitudinal change towards considering community-managed forests as business enterprises would help forest users to visualize goals and streamline their expectations accordingly. In this line, developing management plans and business model scenarios which balance the ecological and socio-economic goals at the local level and consider the needs and priorities of heterogeneous groups of forest users and provide diverse and locally contextualized incentives is important for improving the governance of community-managed forests. Finally, revisiting the practice of the campaign approach in implementing forest policies would be 
central to avoid inconsistent efforts with limited effects in improving the governance of community-managed forests.

Author Contributions: Both authors have made a substantial, direct, and intellectual contribution to the work, and approved it for publication. All authors have read and agreed to the published version of the manuscript.

Funding: This work is part of the RALENTIR (Reducing land degradation and carbon loss from Ethiopia's soils to strengthen livelihoods and resilience) project, funded by UK Research and Innovation, GCRF (Global Challenges Research Fund, project reference ES/T003073/1) and the University of Aberdeen.

Institutional Review Board Statement: Not applicable.

Informed Consent Statement: Not applicable.

Data Availability Statement: Not applicable.

Acknowledgments: We would like to thank Jude Ndzifon Kimengsi and Jan Grabek for their comments on earlier versions of this article. We are grateful for the two anonymous reviewers for their constructive feedback.

Conflicts of Interest: The authors declare no conflict of interest.

\section{References}

1. Turyahabwe, N.; Geldenhuys, C.J.; Watts, S.; Obua, J. Local organisations and decentralised forest management in Uganda: Roles, challenges and policy implications. Int. For. Rev. 2007, 9, 581-596. [CrossRef]

2. Turyahabwe, N.; Agea, J.G.; Tweheyo, M.; Tumwebaze, S.B. Collaborative forest management in Uganda: Benefits, implementation challenges and future directions. In Sustainable Forest Management: Case Studies; IntechOpen: London, UK, 2012 ; Volume 51.

3. Mogaka, H. Economic Aspects of Community Involvement in Sustainable Forest Management in Eastern and Southern Africa; IUCN: Gland, Switzerland, 2001.

4. Lewark, S.; George, L.; Karmann, M. Study of gender equality in community-based forest certification programmes in Nepal. Int. For. Rev. 2011, 13, 195-204. [CrossRef]

5. Banana, A.Y.; Bukenya, M.; Arinaitwe, E.; Birabwa, B.; Ssekindi, S. Gender, Tenure and Community Forests in Uganda; Center for International Forestry Research: Bogor Regency, Indonesia, 2012.

6. $\quad$ Lescuyer, G.; Kakundika, T.M.; Lubala, I.M.; Ekyamba, I.S.; Tsanga, R.; Cerutti, P.O. Are community forests a viable model for the Democratic Republic of Congo? Ecol. Soc. 2019, 24, 6. [CrossRef]

7. Yami, M.; Vogl, C.; Hauser, M. Comparing the effectiveness of informal and formal institutions in sustainable common pool resources management in Sub-Saharan Africa. Conserv. Soc. 2009, 7, 153-164. [CrossRef]

8. Magessa, K.; Wynne-Jones, S.; Hockley, N. Are policies for decentralised forest governance designed to achieve full devolution? Evidence from Eastern Africa. Int. For. Rev. 2020, 22, 83. [CrossRef]

9. Ribot, J.C.; Lund, J.F.; Treue, T. Democratic decentralization in sub-Saharan Africa: Its contribution to forest management, livelihoods, and enfranchisement. Environ. Conserv. 2010, 37, 35-44. [CrossRef]

10. Hayes, T.; Persha, L. Nesting local forestry initiatives: Revisiting community forest management in a REDD+ world. For. Policy Econ. 2010, 12, 545-553. [CrossRef]

11. Paudyal, K.; Baral, H.; Bhandari, S.P.; Keenan, R.J. Design considerations in supporting payments for ecosystem services from community-managed forests in Nepal. Ecosyst. Serv. 2018, 30, 61-72. [CrossRef]

12. Poteete, A.R.; Ostrom, E. Heterogeneity, group size and collective action: The role of institutions in forest management. Dev. Chang. 2004, 35, 435-461. [CrossRef]

13. Van Klingeren, F.; de Graaf, N.D. Heterogeneity, trust and common-pool resource management. J. Environ. Stud. Sci. 2021, 11, 37-64. [CrossRef]

14. Cashore, B. Key components of good forest governance in ASEAN Part I: Overarching principles and criteria. Exlibris 2009, 6, 1-8.

15. Giessen, L.; Buttoud, G. Assessing forest governance-analytical concepts and their application. For. Policy Econ. $2014,49,1-71$. [CrossRef]

16. Secco, L.; da Re, R.; Pettenella, M.D.; Gatto, P. Why and how to measure forest governance at local level: A set of indicators. For. Policy Econ. 2014, 49, 57-71.

17. Rametsteiner, E. Governance concepts and their application in forest policy initiatives from global to local levels. Small-Scale For. 2009, 8, 143-158. [CrossRef]

18. Andersson, K.; Benavides, J.P.; León, R. Institutional diversity and local forest governance. Environ. Sci. Policy 2014, 36, 61-72. [CrossRef]

19. Leach, M.; Mearns, R.; Scoones, I. Challenges to community-based sustainable development: Dynamics, entitlements, institutions. IDS Bull. 1997, 28, 4-14. [CrossRef] 
20. Appiah-Opoku, S.; Mulamoottil, G. Indigenous institutions and environmental assessment: The case of Ghana. Environ. Manag. 1997, 21, 159-171. [CrossRef]

21. Górriz-Mifsud, E.; Secco, L.; Pisani, E. Exploring the interlinkages between governance and social capital: A dynamic model for forestry. For. Policy Econ. 2016, 65, 25-36. [CrossRef]

22. Kahsay, G.A.; Bulte, E. Trust, regulation and participatory forest management: Micro-level evidence on forest governance from Ethiopia. World Dev. 2019, 120, 118-132. [CrossRef]

23. Lacuna-Richman, C.; Devkota, B.P.; Richman, M.A. Users' priorities for good governance in community forestry: Two cases from Nepal's Terai Region. For. Policy Econ. 2016, 65, 69-78. [CrossRef]

24. Pretty, J. The Many Interpretations of Participation. Focus 1995, 16, 4-5.

25. Johnson, N.; Lilja, N.; Ashby, J.A.; Garcia, J.A. The practice of participatory research and gender analysis in natural resource management. Nat. Resour. Forum 2004, 28, 189-200. [CrossRef]

26. Arnstein, S.R. A ladder of citizen participation. J. Am. Inst. Plan. 1969, 35, 216-224. [CrossRef]

27. Gisselquist, R.M. Good Governance as a Concept, and Why this Matters for Development Policy; WIDER Working Paper: Helsinki, Finland, 2012.

28. Essougong, U.P.K.; Foundjem-Tita, D.; Minang, P.A. Addressing equity in community forestry. Ecol. Soc. 2019, 24, 9. [CrossRef]

29. Andersson, K.; Agrawal, A. Inequalities, institutions, and forest commons. Glob. Environ. Chang. 2011, 21, 866-875. [CrossRef]

30. Asefa, M.; Cao, M.; He, Y.; Mekonnen, E.; Song, X.; Yang, J. Ethiopian vegetation types, climate and topography. Plant Divers. 2020, 42, 302-311. [CrossRef]

31. The Food and Agriculture Organization of the United Nations (FAO). Global Forest Resources Assessment 2020, Report, Ethiopia; FAO: Quebec City, QC, Canada, 2020.

32. The Food and Agriculture Organization of the United Nations (FAO). Global Forest Resources Assessment 2020, Report, Kenya; FAO: Quebec City, QC, Canada, 2020.

33. The Food and Agriculture Organization of the United Nations (FAO). Global Forest Resources Assessment 2020, Report, Uganda; FAO: Quebec City, QC, Canada, 2020.

34. Pankhurst, A. Natural resource management institutions in post- conflict situations: State and community forests in Yegof, South Wello, Ethiopia. In Marena Research Project Working Article No. 6; Forum for Social Studies; Addis Ababa University: Addis Ababa, Ethiopia, 2001.

35. Stellmacher, T. The historical development of local forest governance in Ethiopia: From imperial times to the military regime of the Derg. Afr. Spectr. 2007, 42, 519-530.

36. Hoben, A. Paradigms and Politics: The Cultural Construction of Environmental Policy in Ethiopia. World Dev. 1995, 23, 1007-1021. [CrossRef]

37. Bishaw, B. Deforestation and Land Degradation in the Ethiopian Highlands: A Strategy for Physical Recovery. Northeast Afr. Stud. 2001, 8, 7-25. [CrossRef]

38. Cavendish, W. How Do Forests Support, Insure and Improve the Livelihoods of the Rural Poor? Research Note, Cifor, Bogota, Indonesia; Center for International Forestry Research: Bogor, Indonesia, 2013.

39. Cavendish, W. Empirical regularities in the poverty-environment relationship of rural households: Evidence from Zimbabwe. World Dev. 2000, 28, 1979-2003. [CrossRef]

40. Appiah, M.; Blay, D.; Damnyag, L.; Dwomoh, F.K.; Pappinen, A.; Luukkanen, O. Dependence on forest resources and tropical deforestation in Ghana. Environ. Dev. Sustain. 2009, 11, 471-487. [CrossRef]

41. Kelbessa, E.; De Stoop, C. Participatory forest management (PFM) biodiversity and livelihoods in Africa. In Proceedings of the International Conference, Addis Ababa, Ethiopia, 19-21 March 2007.

42. Winberg, E. Participatory Forest Management in Ethiopia, Practices and Experiences; Food and Agriculture Organization of the United Nations, Subregional Office for Eastern Africa: Addis Ababa, Ethiopia, 2007.

43. Bekele, M. Ethiopia's environmental policies, strategies and programs. In Digest of Ethiopia's National Policies, Strategies and Programs; FSS: Addis Ababa, Ethiopia, 2008; pp. 337-369.

44. Shylendra, H.S. Environmental rehabilitation and livelihood impact: Emerging trends from Ethiopia and Gujarat. Econ. Political Wkly. 2002, 37, 3286-3292.

45. Derero, A.; Mamo, N.; Kelemu, K. Strategic Actions for Integrated Forest Development in Ethiopia; Ethiopian Institute of Agricultural Research: Addis Ababa, Ethiopia, 2011.

46. Chisholm, N. Maintaining a fragile balance: Community management of renewable natural resources in Tigray, NE Ethiopia. In Presented at: "Constituting the Commons: Crafting Sustainable Commons in the New Millenium", Proceedings of the Eighth Conference of the International Association for the Study of Common Property, Bloomington, IN, USA, 31 May-4 June 2000; Indiana University: Bloomington, IN, USA, 2000.

47. Lemenih, M.; Kassa, H. Re-greening Ethiopia: History, challenges and lessons. Forests 2014, 5, 1896-1909. [CrossRef]

48. Mekonnen, A. Valuation of community forestry in Ethiopia: A contingent valuation study of rural households. Environ. Dev. Econ. 2000, 5, 289-308. [CrossRef]

49. Siraj, M.; Zhang, K.; Xiao, W.; Bilal, A.; Gemechu, S.; Geda, K.; Xiaodan, L. Does participatory forest management save the remnant forest in Ethiopia? Proc. Natl. Acad. Sci. India Sect. B Biol. Sci. 2018, 88, 1-14. [CrossRef] 
50. Descheemaeker, K.; Nyssen, J.; Poesen, J.; Raes, D.; Haile, M.; Muys, B.; Deckers, S. Runoff on slopes with restoring vegetation: A case study from the Tigray highlands, Ethiopia. J. Hydrol. 2006, 331, 219-241. [CrossRef]

51. Birhane, E.; Mengistu, T.; Seyoum, Y.; Hagazi, N.; Putzel, L.; Rannestad, M.M.; Kassa, H. Exclosures as forest and landscape restoration tools: Lessons from Tigray Region, Ethiopia. Int. For. Rev. 2017, 19, 37-50. [CrossRef]

52. Yami, M.; Mekuria, W.; Hauser, M. The effectiveness of village bylaws in sustainable management of community-managed exclosures in Northern Ethiopia. Sustain. Sci. 2013, 8, 73-86. [CrossRef]

53. Yami, M.; Sarmiento Barletti, J.P.; Larson, A.M. Can multi-stakeholder forums influence good governance in communal forest management? Lessons from two case studies in Ethiopia. Int. For. Rev. 2021, 23, 24-42. [CrossRef]

54. Wassie, A.; Teketay, D.; Powell, N.E.I.L. Church forests in north Gonder administrative zone, northern Ethiopia. For. Trees Livelihoods 2005, 15, 349-373. [CrossRef]

55. Klepeis, P.; Orlowska, I.A.; Kent, E.F.; Cardelús, C.L.; Scull, P.; Eshete, A.W.; Woods, C. Ethiopian church forests: A hybrid model of protection. Hum. Ecol. 2016, 44, 715-730. [CrossRef]

56. Mengistu, T.; Teketay, D.; Hulte'n, H.; Yemishaw, Y. The role of communities in closed area management in Ethiopia. J. Mt. Res. Dev. 2005, 25, 44-50.

57. Ayana, A.N.; Vandenabeele, N.; Arts, B. Performance of participatory forest management in Ethiopia: Institutional arrangement versus local practices. Crit. Policy Stud. 2015, 11, 19-38. [CrossRef]

58. Teketay, D. Deforestation, wood famine, and environmental degradation in Ethiopia's highland ecosystems: Urgent need for action. Northeast Afr. Stud. 2001, 8, 53-76. [CrossRef]

59. Mekuria, W.; Yami, M.; Haile, M.; Gebrehiwot, K.; Birhane, E. Impact of exclosures on wood biomass production and fuelwood supply in northern Ethiopia. J. For. Res. 2019, 30, 629-637. [CrossRef]

60. Pistorius, T.; Carodenuto, S.; Wathum, G. Implementing forest landscape restoration in Ethiopia. Forests 2017, 8, 61. [CrossRef]

61. Woldie, B.A.; Tadesse, S.A. Views and attitudes of local people towards community versus state forest governance in Tehulederi District, South Wollo, Ethiopia. Ecol. Processes 2019, 8, 4. [CrossRef]

62. Mekonnen, A. Tenure security, resource endowments, and tree growing: Evidence from the Amhara region of Ethiopia. Land Econ. 2009, 85, 292-307. [CrossRef]

63. Bekele, T.; Kassa, K.; Mengistu, T.; Debele, M.; Melka, Y. Working with communities to address deforestation in the Wondo Genet Catchment Area, Ethiopia: Lessons learnt from a participatory action research. Res. J. Agric. Environ. Manag. 2013, 2, $448-456$.

64. Yayneshet, T.; Eik, L.O.; Moe, S.R. The effects of exclosures in restoring degraded semi-arid vegetation in communal grazing lands in northern Ethiopia. J. Arid. Environ. 2009, 73, 542-549. [CrossRef]

65. Mekuria, W.; Veldkamp, E.; Corre, M.D.; Haile, M. Restoration of ecosystem carbon stocks following exclosure establishment in communal grazing lands in Tigray, Ethiopia. Soil Sci. Soc. Am. J. 2011, 75, 246-256. [CrossRef]

66. Mekuria, W.; Langan, S.; Johnston, R.; Belay, B.; Amare, D.; Gashaw, T.; Desta, G.; Noble, A.; Wale, A. Restoring aboveground carbon and biodiversity: A case study from the Nile basin, Ethiopia. For. Sci. Technol. 2015, 11, 86-96. [CrossRef]

67. Mekuria, W.; Langan, S.; Noble, A.; Johnston, R. Soil restoration after seven years of exclosure management in Northwestern Ethiopia. Land Degrad. Dev. 2017, 28, 1287-1297. [CrossRef]

68. Balana, B.B.; Muys, B.; Haregeweyn, N.; Descheemaeker, K.; Deckers, J.; Poesen, J.; Nyssen, J.; Mathijs, E. Cost-benefit analysis of soil and water conservation measures: The case of exclosures in northern Ethiopia. For. Policy Econ. 2012, 15, 27-36. [CrossRef]

69. Beyene, A.D.; Mekonnen, A.; Randall, B.; Deribe, R. Household level determinants of agroforestry practices adoption in rural Ethiopia. For. Trees Livelihoods 2019, 28, 194-213. [CrossRef]

70. Tesfaye, Y.; Roos, A.; Campbell, B.M.; Bohlin, F. Livelihood strategies and the role of forest income in participatory-managed forests of Dodola area in the bale highlands, southern Ethiopia. For. Policy Econ. 2011, 13, 258-265. [CrossRef]

71. Gebreegziabher, Z.; Mekonnen, A.; Gebremedhin, B.; Beyene, A.D. Determinants of success of community forestry: Empirical evidence from Ethiopia. World Dev. 2021, 138, 105206. [CrossRef]

72. Watson, E. Inter Institutional Alliances and Conflicts in Natural Resource Management: Preliminary Research Findings from Borana, Oromia Region, Ethiopia. In Working Article No. 4. Marena Research Project; 2001. Available online: https://www.ogiek. org/indepth/cbnrm-sussex-01-paper-04.pdf (accessed on 14 December 2021).

73. Watson, E. Examining the potential of indigenous institutions for development: A perspective from Borana, Ethiopia. Dev. Chang. 2003, 34, 287-309. [CrossRef]

74. Wakjira, D.T.; Gole, T.W. Customary forest tenure in southwest Ethiopia. For. Trees Livelihoods 2007, 17, 325-338. [CrossRef]

75. Bakala, F.; Asfaw, M.; Tadesse, B. Factors Influencing Household Participation in a Participatory Forest Management Scheme: Bench-Sheko Zone, Southwest Ethiopia. J. Sustain. For. 2021, 1-13. [CrossRef]

76. Hart, C. Doing a Literature Search: A Comprehensive Guide for the Social Sciences; Sage: New York, NY, USA, 2001.

77. Kacho, B.; Asfaw, M. Factors Influencing Participation of the Local Community in Natural Resource Conservation: A Comparative Study of Chiro and Fiche, Ethiopia. Public Policy Adm. Res. 2014, 4, 48-56.

78. Ameha, A.; Larsen, H.O.; Lemenih, M. Participatory forest management in Ethiopia: Learning from pilot projects. Environ. Manag. 2014, 53, 838-854. [CrossRef] [PubMed]

79. Adego, T.; Simane, B.; Woldie, G.A. Sustainability, institutional arrangement and challenges of community-based climate smart practices in northwest Ethiopia. Agric. Food Secur. 2018, 7, 56. [CrossRef] 
80. Tadesse, S.; Woldetsadik, M.; Senbeta, F. Attitudes of Forest Users towards Participatory Forest Management: The Case of Gebradima Forest, Southwestern Ethiopia. Small-Scale For. 2018, 17, 293-308. [CrossRef]

81. Ariti, A.T.; van Vliet, J.; Verburg, P.H. What restrains Ethiopian NGOs to participate in the development of policies for natural resource management? Environ. Sci. Policy 2018, 89, 292-299. [CrossRef]

82. Walle, Y.; Nayak, D. How Can Participatory Forest Management Cooperatives Be Successful in Forest Resources Conservation? An Evidence from Ethiopia. J. Sustain. For. 2019, 39, 1-19. [CrossRef]

83. Tesfaye, Y.; Roos, A.; Campbell, B.M.; Bohlin, F. Forest incomes and poverty alleviation under participatory forest management in the Bale Highlands, Southern Ethiopia. Int. For. Rev. 2010, 12, 66-77.

84. Kemerink-Seyoum, J.S.; Tadesse, T.M.; Mersha, W.K.; Duker, A.E.C.; De Fraiture, C. Sharing benefits or fueling conflicts? The elusive quest for organizational blue-prints in climate financed forestry projects in Ethiopia. Glob. Environ. Chang. 2018, 53, 265-272. [CrossRef]

85. Wakjira, D.T.; Fischer, A.; Pinard, M.A. Governance change and institutional adaptation: A case study from Harenna Forest, Ethiopia. Environ. Manag. 2013, 51, 912-925. [CrossRef]

86. Tekalign, T.; Kaba, U.; Zerihun, K. Challenges for improving forest conditions and forest-based livelihoods through participatory forest management around Bonga, southwestern Ethiopia. Int. For. Rev. 2015, 17, 355-367. [CrossRef]

87. Saguye, T.S. Empirical Analysis of the Reality of Gender Inclusiveness of Participatory Forest Management Approach: The Case of Chilimo-Gaji Forest, West Shewa Zone, Oromia Region, Ethiopia. Int. J. Sci. Technol. Soc. 2017, 5, 74. [CrossRef]

88. Tadesse, S.; Woldetsadik MSenbeta, F. Forest users' level of participation in a participatory forest management program in southwestern Ethiopia. For. Sci. Technol. 2017, 13, 164-173. [CrossRef]

89. Nigussie, Z.; Tsunekawa, A.; Haregeweyn, N.; Adgo, E.; Cochrane, L.; Floquet, A.; Abele, S. Applying Ostrom's institutional analysis and development framework to soil and water conservation activities in north-western Ethiopia. Land Use Policy 2018, 71, 1-10. [CrossRef]

90. Girma, W.; Beyene, F. Willingness to contribute to collective forest management: Evidence from Godere in the Gambela Region of Ethiopia. J. Socio-Econ. 2012, 41, 79-86. [CrossRef]

91. Gatiso, T.T. Households' dependence on community forest and their contribution to participatory forest management: Evidence from rural Ethiopia. Environ. Dev. Sustain. 2019, 21, 181-197. [CrossRef]

92. Segers, K.; Dessein, J.; Hagberg, S.; Develtere, P.; Haile, M.; Deckers, J. Be like bees-The politics of mobilizing farmers for development in Tigray, Ethiopia. Afr. Aff. 2009, 108, 91-109. [CrossRef]

93. Yami MSnyder, K. After all, land belongs to the state": Examining the Benefits of Land Registration for Smallholders in Ethiopia. Land Degrad. Dev. 2016, 27, 465-478. [CrossRef]

94. Yami, M.; Vogl CHauser, M. Informal Institutions as Mechanisms to Address Challenges in Communal Grazing Land Management in Tigray, Ethiopia. Int. J. Sustain. Dev. World Ecol. 2011, 18, 78-87. [CrossRef]

95. Gelo, D.; Koch, S.F. The impact of common property right forestry: Evidence from Ethiopian villages. World Dev. 2014, 64, 395-406. [CrossRef]

96. Brown, D.R.; Dettmann, P.; Rinaudo, T.; Tefera, H.; Tofu, A. Poverty alleviation and environmental restoration using the clean development mechanism: A case study from Humbo, Ethiopia. Environ. Manag. 2011, 48, 322-333. [CrossRef]

97. Mohammed, A.J.; Inoue, M. Drawbacks of decentralized natural resource management: Experience from Chilimo Participatory Forest Management project, Ethiopia. J. For. Res. 2012, 17, 30-36. [CrossRef]

98. Mohammed, A.J.; Inoue, M. Explaining disparity in outcome from community-based natural resource management (CBNRM): A case study in Chilimo Forest, Ethiopia. J. Environ. Plan. Manag. 2012, 55, 1248-1267. [CrossRef]

99. Shumi, G.; Dorresteijn, I.; Schultner, J.; Hylander, K.; Senbeta, F.; Hanspach, J.; Fischer, J. Woody plant use and management in relation to property rights: A social-ecological case study from southwestern Ethiopia. Ecosyst. People 2019, 15, 303-316. [CrossRef]

100. Mamo, G.; Sjaastad, E.; Vedeld, P. Economic dependence on forest resources: A case from Dendi District, Ethiopia. For. Policy Econ. 2007, 9, 916-927. [CrossRef]

101. Byg, A.; Novo, P.; Dinato, M.; Moges, A.; Tefera, T.; Balana, B.; Black, H. Trees, soils, and warthogs-distribution of services and disservices from reforestation areas in Southern Ethiopia. For. Policy Econ. 2017, 84, 112-119. [CrossRef]

102. Gebregziabher, D.; Soltani, A.; Hofstad, O. Equity in the distribution of values of outputs from exclosures in Tigray, Ethiopia. J. Arid. Environ. 2017, 146, 75-85. [CrossRef]

103. Kidu, G.; Gebremedhin, B.; Birhane, E.; Kassa, H. Does communal forest intervention management enhance forest benefits of smallholder farmers? Evidence from Hugumbirda forest, Tigray, Ethiopia. J. Sustain. For. 2017, 36, 264-276. [CrossRef]

104. Stellmacher, T. Local Forest Governance in Ethiopia: Between Legal Pluralism and Livelihood Realities; ZEF Working Paper Series; ZEF: Bonn, Germany, 2013; No. 110.

105. Gatiso, T.T.; Vollan, B. Democracy and cooperation in commons management: Experimental evidence of representative and direct democracy from community forests in Ethiopia. Environ. Dev. Econ. 2017, 22, 110-132. [CrossRef]

106. Demissie, F.; Yeshitela, K.; Rouleau, M.; Flaspohler, D.; Kindu, M. Socio-economic importance of forest resources and their conservation measures in Ethiopia: The case of area closure in South Gonder of Ethiopia. Environ. Monit. Assess. 2019, 191, 437. [CrossRef] 
107. Wood, A.; Tolera, M.; Snell, M.; O'Hara, P.; Hailu, A. Community forest management (CFM) in south-west Ethiopia: Maintaining forests, biodiversity and carbon stocks to support wild coffee conservation. Glob. Environ. Chang. 2019, 59, 101980. [CrossRef]

108. Kassa, H.; Birhane, E.; Bekele, M.; Lemenih, M.; Tadesse, W.; Cronkleton, P.; Baral, H. Shared strengths and limitations of participatory forest management and area exclosure: Two major state led landscape rehabilitation mechanisms in Ethiopia. Int. For. Rev. 2017, 19, 51-61. [CrossRef]

109. Tadesse, S.A.; Teketay, D. Perceptions and attitudes of local people towards participatory forest management in Tarmaber District of North Shewa Administrative Zone, Ethiopia: The case of Wof-Washa Forests. Ecol. Processes 2017, 6, 17. [CrossRef]

110. Gebregziabher, D.; Soltani, A. Exclosures in people's minds: Perceptions and attitudes in the Tigray region, Ethiopia. For. Policy Econ. 2019, 101, 1-14. [CrossRef]

111. Gobeze, T.; Bekele, M.; Lemenih, M.; Kassa, H. Participatory forest management and its impacts on livelihoods and forest status: The case of Bonga forest in Ethiopia. Int. For. Rev. 2009, 11, 346-358. [CrossRef]

112. Balana, B.B.; Mathijs, E.; Muys, B. Assessing the sustainability of forest management: An application of multi-criteria decision analysis to community forests in northern Ethiopia. J. Environ. Manag. 2010, 91, 1294-1304. [CrossRef] [PubMed]

113. Tesfaye, Y.; Roos, A.; Campbell, B.J.; Bohlin, F. Factors associated with the performance of user groups in a participatory forest management around Dodola forest in the Bale mountains, Southern Ethiopia. J. Dev. Stud. 2012, 48, 1665-1682. [CrossRef]

114. Kedir, H.; Negash, M.; Yimer, F.; Limenih, M. Contribution of participatory forest management towards conservation and rehabilitation of dry Afromontane forests and its implications for carbon management in the tropical Southeastern Highlands of Ethiopia. J. Sustain. For. 2018, 37, 357-374. [CrossRef]

115. Mohammed, A.J.; Inoue, M. Exploring decentralized forest management in Ethiopia using actor-power-accountability framework: Case study in West Shoa zone. Environ. Dev. Sustain. 2013, 15, 807-825. [CrossRef]

116. Mohammed, A.J.; Inoue, M.; Shivakoti, G. Moving forward in collaborative forest management: Role of external actors for sustainable Forest socio-ecological systems. For. Policy Econ. 2017, 74, 13-19. [CrossRef]

117. Kosfeld, M.; Rustagi, D. Leader punishment and cooperation in groups: Experimental field evidence from commons management in Ethiopia. Am. Econ. Rev. 2015, 105, 747-783. [CrossRef]

118. Cronkleton, P.; Artati, Y.; Baral, H.; Paudyal, K.; Banjane, M.R.; Liu, J.L.; Kassa, H. How do property rights reforms provide incentives for forest landscape restoration? Comparing evidence from Nepal, China and Ethiopia. Int. For. Rev. 2017, 19, 8-23. [CrossRef]

119. Mekuria, W.; Gebregziabher, G.; Lefore, N. Exclosures for Landscape Restoration in Ethiopia: Business Model Scenarios and Suitability; IWMI Research Report 175; International Water Management Institute (IWMI): Colombo, Sri Lanka, 2020; 62p.

120. Ameha, A.; Nielsen, O.J.; Larsen, H.O. Impacts of access and benefit sharing on livelihoods and forest: Case of participatory forest management in Ethiopia. Ecol. Econ. 2014, 97, 162-171. [CrossRef]

121. Oniki, S.; Berhe, M.; Negash, T. Role of Social Norms in Natural Resource Management: The Case of the Communal Land Distribution Program in Northern Ethiopia. Land 2020, 9, 35. [CrossRef]

122. Murugan, P.; Israel, F. Impact of Forest Carbon Sequestration Initiative on Community Assets: The Case of Assisted Natural Regeneration Project in Humbo, Southwestern Ethiopia. Afr. Stud. Q. 2017, 17, 23-42.

123. Gelo, D.; Koch, S.F.; Muchapondwa, E. Do the poor benefit from devolution policies? Evidences from quantile treatment effect evaluation of joint forest management. In Economic Research Southern Africa (ERSA) Working Paper; Economic Research Southern Africa: Cape Town, South Africa, 2013; Volume 400.

124. Gashu, K.; Aminu, O. Participatory forest management and smallholder farmers' livelihoods improvement nexus in Northwest Ethiopia. J. Sustain. For. 2019, 38, 413-426. [CrossRef]

125. Bekele, T.; Ango, T.G. Do interventions from participatory action research improve livelihood and reduce conflicts over forest resources? A case study from south central Ethiopia. Small-Scale For. 2015, 14, 441-458. [CrossRef]

126. Cashore, B.; Bernstein, S.; Humphreys, D.; Visseren-Hamakers, I.; Rietig, K. Designing stakeholder learning dialogues for effective global governance. Policy Soc. 2019, 38, 118-147. [CrossRef]

127. Harrison, E. The problem with the locals': Partnership and participation in Ethiopia. Dev. Chang. 2002, 33, 587-610. [CrossRef]

128. Ashenafi, Z.T.; Leader-Williams, N. Indigenous common property resource management in the Central Highlands of Ethiopia. Hum. Ecol. 2005, 33, 539-563. [CrossRef]

129. Haller, T.; Acciaioli, G.; Rist, S. Constitutionality: Conditions for crafting local ownership of institution-building processes. Soc. Nat. Resour. 2016, 29, 68-87. [CrossRef]

130. Haller, T.; Merten, S. Crafting our own rules: Constitutionality as a bottom-up approach for the development of by-laws in Zambia. Hum. Ecol. 2018, 46, 3-13. [CrossRef]

131. Lachapelle, P.R.; Smith, P.D.; McCool, S.F. Access to power or genuine empowerment? An analysis of three community forest groups in Nepal. Hum. Ecol. Rev. 2004, 11,1-12.

132. Li, T.M. The Will to Improve: Governmentality, Development, and the Practice of Politics; Duke University Press: Durham, NC, USA, 2007.

133. Brancalion, P.H.; Niamir, A.; Broadbent, E.; Crouzeilles, R.; Barros, F.S.; Zambrano, A.M.A.; Chazdon, R.L. Global restoration opportunities in tropical rainforest landscapes. Sci. Adv. 2019, 5, eaav3223. [CrossRef] [PubMed] 
134. Stanturf, J.A.; Kleine, M.; Mansourian, S.; Parrotta, J.; Madsen, P.; Kant, P.; Bolte, A. Implementing forest landscape restoration under the Bonn Challenge: A systematic approach. Ann. For. Sci. 2019, 76, 50. [CrossRef]

135. Beyene, A.D.; Bluffstone, R.; Mekonnen, A. Community forests, carbon sequestration and REDD+: Evidence from Ethiopia. Environ. Dev. Econ. 2016, 21, 249-272. [CrossRef] 